\title{
A Third Benefit of Joint Non-OPEC Carbon Taxes: Transferring OPEC Monopoly Rent
}

\author{
YAN DONG \\ JOHN WHALLEY
}

CESIFO WORKING PAPER NO. 2741

CATEgORY 8: TRAde Policy

August 2009

\footnotetext{
An electronic version of the paper may be downloaded

- from the SSRN website:

www.SSRN.com

- from the RePEc website:

www.RePEc.org

- from the CESifo website:

www.CESifo-group.org/wp
} 


\title{
A Third Benefit of Joint Non-OPEC Carbon Taxes: Transferring OPEC Monopoly Rent
}

\begin{abstract}
This paper highlights the potential for joint OECD (or non-OPEC) carbon taxes to reduce OPEC's monopoly rent and provide benefit to non-OPEC countries provided jointly agreed trigger strategies are adhered to. In traditional economic theory, the primary purpose of a carbon tax is to internalize a global negative externality. A second benefit for individual countries is that the revenue raised by carbon tax can be used to reduce other tax rates and so lower the deadweight loss of tax system. In this paper, we discuss a third benefit of carbon taxes: transferring rents from OPEC to the oil importing countries.

We develop a multi-region general equilibrium structure with endogenously determined oil supply for the purpose in which emissions are endogenously determined. We calibrate our model to 2006 data. Our analytics and numerical simulation results highlight how a uniform carbon tax used by all non-OPEC countries will increase the buyer's price of oil but decrease the supplier's price of oil, thus decreasing non-OPEC countries' oil demand, and transferring OPEC monopoly rent to non-OPEC countries. Carbon taxes reduce the welfare of OPEC and increase the welfare of non-OPEC countries. Results also show how carbon taxes reduce global emissions, but the effect is small.
\end{abstract}

JEL Code: Z19.

Keywords: carbon taxes, OECD, monopoly rent.

Yan Dong

Chinese Academy of Social Sciences and University of Western Ontario
John Whalley

University of Western Ontario

Centre for International Governance

Innovation (CIGI)

jwhalley@uwo.ca

May 2009

We are grateful to the Center for International Governance Innovation (CIGI), and the Academic Development Fund of the University of Western Ontario, and the Ontario Research Fund for financial support. 


\section{Introduction}

This paper discusses the role of jointly applied non-OPEC carbon taxes supported by appropriate trigger price mechanisms in reducing OPEC's monopoly rent. A carbon tax is an environmental tax on emissions of carbon dioxide and other greenhouse gases, the purpose of which is to slow climate change by reducing emissions. With concerns over severe effects from global warming, some major economies have paid much attention to carbon tax, and limited taxes of this type been enacted in some European Union countries, such as Sweden, Finland, the Netherlands, Norway, Italy and The United Kingdom. There are also similar proposals in U.S., Canada, and some developing countries, such as China. Another important issue is that OPEC has monopoly power in the world oil market and extracts significant monopoly rent. In this paper, we combine these issues and discuss how a jointly implemented non-OPEC countries' carbon tax can also reduce OPEC’s monopoly power to the advantage of the non-OPEC.

Traditional economic theory sees pollution as a negative externality and the primary purpose of a carbon tax is to internalize such a negative externality. This was discussed by Pigou(1938) as the internalization of externalities using Pigouvian Tax. Later, Terkla(1984), Pearce(1991) and others discussed the “double dividend” from a carbon tax; a carbon tax will not only reduces the distortionary loss from the externality, the revenue raised by the tax can also be used to reduce other distortionary taxes, and so lower the deadweight loss of tax system. Globally, there is a cleaner environment with less global warming, while also improving incentives for productive activities.

In this paper, we discuss a third benefit to non-OPEC countries from a joint carbon tax with appropriate supporting trigger strategies: transferring rents from OPEC to the oil importing countries. Carbon taxes reduce the consumption of oil in importing countries, reduce OPEC's production price of oil and rents are transferred to the non-OPEC oil importing countries. Lerner (1980) proposed a plan for using taxes in this way to break OPEC. He advocated that a specific tax with trigger 
strategies that the United States and governments of oil-consuming countries impose a 100 percent excise tax on the difference between OPEC's price and the pre-OPEC price adjusted for inflation. Lerner's plan would double consumers' elasticity of demand causing them to demand less oil at higher prices and thus reduce the strength of the cartel. His plan was not promoted for environmental purposes and was never adopted, but our analysis is in the spirit of this proposal. In discussing the possible influences of environmental agreements on OPEC, a range of present oil-economy models estimate that OPEC will lose from the Kyoto Protocol(see Barnett et al.(2004),Ghanem et al.(1999), McKibbin et al.(1999), Bernstein et al.(1999)), but none have linked these effects to the carbon tax in numerical modeling.

We develop a multi-region general equilibrium structure in which countries produce commodities of varying emissions intensities using substitutable fossil fuel based oil and non-oil inputs as in Dong \& Whalley (2009). Unlike in conventional trade models in which there is a fixed endowment of factor inputs for each country, here we model a supply function for each country reflecting increasing extraction costs. We model the extraction cost function in constant elasticity form to yield a specification consistent with alternative values of the supply elasticity of oil. To our knowledge, this structure, while simple, is novel in numerical work.

We next turn to numerical simulation, and using a number of data sources construct a benchmark global equilibrium data set based on data for 2006. This covers production, consumption, and trade for five regions (China,EU,US,OPEC,ROW) .We calibrate our model to this data set using literature based estimates of key elasticities, with the exception of production function elasticities which we determine using data on oil prices and marginal cost and Lerner's pricing rule for monopoly producers.

Results show that a uniform carbon tax used by non-OPEC countries increases the oil-importing countries welfare and income, reduces OPEC's welfare and income, and transfers monopoly rents from OPEC to oil-importing countries. The higher the carbon tax, the more rent will be transferred. And carbon taxes also reduce global emissions, but the effect is small. 


\section{A Model of Carbon Tax and OPEC Monopoly Rent Transfers}

We first present our carbon tax model in algebraic form. As we focused on OPEC, we make the strong assumption that oil is the only source of energy. There are five regions, $i=1, \cdots 5$ China, EU, US, OPEC and ROW, there are two goods produced in each region, $j=1,2$. In production, good 1 has high oil cost intensity, and good 2 has low oil cost intensity. The model specifies two factors, $N$ a non-oil input, which is immobile across countries, but mobile across sectors within a country, and $E$ an oil input which is mobile across both countries and sectors.

On the production side, we consider a two sector (a high oil (emission) intensity good and a low oil (emission) intensity good), two factor (oil and non oil input) structure. We assume production is CES. The production function for each good in each country can be written as

$$
Y_{i j}=\Phi_{i j}\left[a_{i j 1}{ }^{1 / \sigma_{s}} E_{i j}^{\sigma_{s}-1 / \sigma_{s}}+a_{i j 2}{ }^{1 / \sigma_{s}} N_{i j}^{\sigma_{s}-1 / \sigma_{s}}\right]^{\sigma_{s} / \sigma_{s}-1} \quad i=\text { country, } j=\text { sector }
$$

where $Y_{i j}$ is the output of good $j$ produced in country $i$, and $\sigma_{s}$ is the elasticity of substitution between the two inputs (assumed similar across countries). $p_{i N}$ is the price of the non-oil input in country $i$, goods prices are $P_{i j}$. We assume that oil is mobile across countries, so that the producer price of oil in each country (the world price) is the same $p_{E}$. tc is the common carbon tax rate .The buyer's price of oil $p_{E B}$ is

$$
p_{E B}=p_{E} \square(1+t c)
$$

First order conditions imply the following:

$$
\begin{aligned}
& E_{i j}=Y_{i j} \Phi_{i j}^{-1} a_{i j 1} p_{E B}^{-\sigma_{s}}\left[a_{i j 1} p_{E B}^{1-\sigma_{s}}+a_{i j 2} p_{i N}^{1-\sigma_{s}}\right]^{\sigma_{S} / 1-\sigma_{s}} \\
& N_{i j}=Y_{i j} \Phi_{i j}^{-1} a_{i j 2} p_{i N}^{-\sigma_{s}}\left[a_{i j 1} p_{E B}^{1-\sigma_{s}}+a_{i j 2} p_{i N}^{1-\sigma_{s}}\right]^{\sigma_{S} / 1-\sigma_{s}}
\end{aligned}
$$

and the domestic composite price is

$$
P_{i j}=\Phi_{i j}^{-1}\left[a_{i j 1} p_{E B}^{1-\sigma_{s}}+a_{i j 2} p_{i N}^{1-\sigma_{s}}\right]^{1 / 1-\sigma_{s}}
$$


Unlike traditional general equilibrium models which use a fixed endowment of oil, here, by introducing an extraction cost function for each country into the model, oil supply by country is now endogenously determined. The extraction cost function we use implies an increasing marginal cost of extraction and is written as

$$
K_{i}=F_{i}\left(Q_{i}\right)=B_{i 1}+B_{i 2} Q_{i}^{B_{i 3}}
$$

where $K_{i}$ is the extraction cost in country $i$, and $Q_{i}$ is oil extraction in country $i$.

From the first-order conditions for the extraction cost function, we get

$$
p_{E}=\frac{d K_{i}}{d Q_{i}}=\frac{d F_{i}\left(Q_{i}\right)}{d Q_{i}}=B_{i 2} B_{i 3} Q_{i}^{B_{i 3}-1}
$$

and the oil supply elasticity is

$$
E Q_{i}=\frac{d K_{i} / K_{i}}{d Q_{i} / Q_{i}}=B_{i 3}-1
$$

Dividing the extraction cost function by the oil price, we can calculate the resources that are used in oil extraction.

$$
R_{i}=\frac{K_{i}}{p_{E}}=\frac{B_{i 1}+B_{i 2} Q_{i}^{B_{i 3}}}{p_{E}}
$$

On the demand side of the model, the representative household utility function in each country is

$$
U_{i}=U_{i}\left(R X_{i}, \Delta T\right)=\left[\gamma_{H i}^{1 / \sigma_{d}} H_{i}^{\sigma_{d}-1 / \sigma_{d}}+\gamma_{L i}^{1 / \sigma_{d}} L_{i}^{\sigma_{d}-1 / \sigma_{d}}\right]^{\sigma_{d}} / \sigma_{d d}-1\left(\frac{C-\Delta T}{C}\right)^{\beta}
$$

This utility function follows Cai, Riezman \& Whalley (2009). $R X_{i}$ is composite consumption in country $i$, while $\Delta T$ is global temperature change. $H_{i}$ is composite high emission goods consumption, $L_{i}$ is composite low emission goods consumption, $\sigma_{d}$ is the substitution elasticity between high and low emission goods, $\beta$ reflects the assumed severity of damage from temperature change. In this specification, $C$ can be thought of as the global temperature change at which all economic activity ceases (say, 
$20^{\circ} \mathrm{C}$ ). In this formulation, as $\Delta T$ approaches $C$, utility goes to zero; and as $\Delta T$ goes to zero, there is no welfare impact of temperature change.

For the final good demand functions, $R X_{i}$ is a two level nested CES function. Each region is assumed to maximize utility by first choosing among high and low oil (emission) intensity goods, and each region then chooses using among domestic goods and the other country goods at a second level.

$$
R X_{i}=f\left(X_{i 11}, X_{i 21}, \cdots X_{i 1 r}, X_{i 2 r}\right)
$$

Each of the five regions maximizes top level utility subject to a budget constraint. $I_{i}$ is income in country $i$.

$$
\sum_{j i^{\prime}} P_{i j i^{\prime}} X_{i j j^{\prime}}=I_{i}
$$

Income includes non-oil income, oil income, tariff revenue, carbon tax revenue and transfers from abroad (financing net goods import and net oil import).

$$
I_{i}=p_{i N} W_{i N}+\left[p_{E} Q_{i}-K_{i}\right]+R_{i}+R C_{i}+T R_{i}
$$

For country $i, p_{i N}$ is the price of non-oil input, $W_{i N}$ is the non-oil endowment, $K_{i}$ is the extraction cost of oil, and $Q_{i}$ is oil extraction in country $i . R_{i}$ is tariff revenue, $R C_{i}$ is carbon tax revenue, and $T R_{i}$ are exogenous transfers between countries (net goods import plus net oil import). These can be zero, but incorporating them allows calibration to unbalanced trade data.

Figure 1 shows the structure of the two level nested CES utility functions used. For each good $j$ produced in country $i$ ', we define the seller's price (net of tariff) as $p_{j i^{\prime}}$, and allow each country $i$ to impose tariffs at rate $t_{i j i^{\prime}}$ ( country $i$ 's tariff on good $j$ imported from country $i^{\prime}$ ) on each imported good. Tariffs are set to zero for exports. Internal (gross of tariff ) prices for good $j$ produced in country $i$ ' are thus

$$
P_{i j i^{\prime}}=\left[1+t_{i j i}\right] P_{j i^{\prime}}
$$




\section{Figure 1 : Two Level Nested CES Utility Functions Used for Each Country}

\section{DEMAND}

Final Demand Functions

In each region, a 2 level CES

functional form is used

\section{CES Hierarchy}

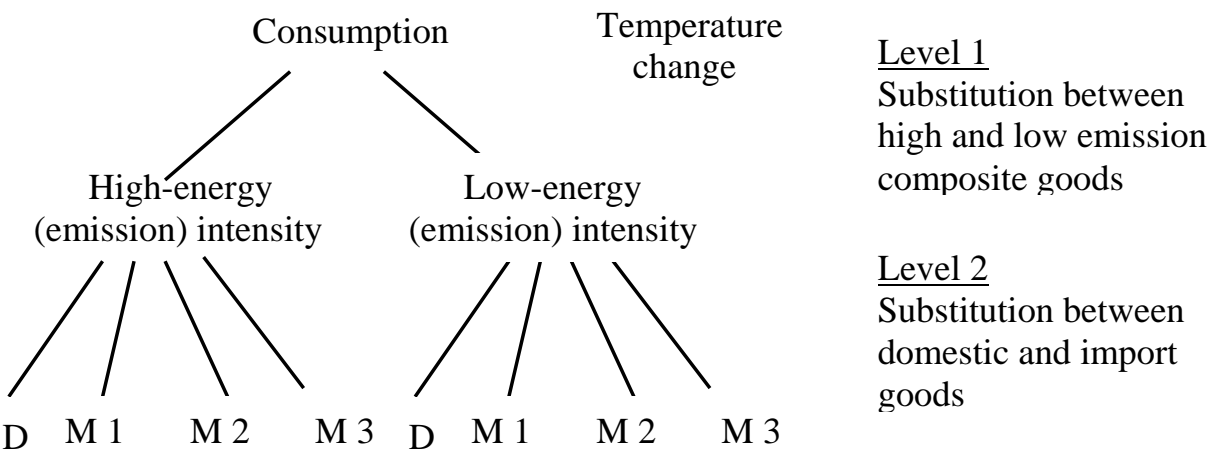

Temperature change in physical form is assumed to be a function of oil consumption, i.e.

$$
\Delta T=g\left(\sum_{i} \sum_{j} E_{i j}\right)=a\left(\sum_{i} \sum_{j} E_{i j}\right)^{b}+c
$$

In equilibrium, goods and factor markets clear. Goods market clearing implies:

$$
\sum_{i} X_{i j i^{\prime}}=Y_{i^{\prime} j} \quad i=1, \cdots 5 \quad j=1,2
$$

Non-oil inputs are only mobile across sectors within regions and immobile across regions, so each region's non-oil input use equals its non-oil endowment. The non-oil factor clearing conditions are:

$$
\sum_{j} N_{i j}=W_{i N} \quad i=1, \cdots 5 \quad j=1,2
$$

Oil is mobile across countries and so global oil consumption equals global oil extraction. The oil clearing condition is:

$$
\sum_{i} \sum_{j} E_{i j}=\sum_{i} Q_{i}
$$




\section{Data and Parameterization}

We build a model compatible benchmark general equilibrium data set which we use in calibration. Our base case include 2006 trade, production, and consumption data (as well as oil use) for a 2 good (energy /non energy intensive), 2 factor (oil inputs, other inputs) structure for 5 regions (China, US , EU, OPEC,ROW).

In Table 1-1 ,GDP data is from the World Bank's WDI database and OPEC Annual Statistics Bulletin 2007. The high-emission sector in each country is taken to be the manufacturing industry. The low-emission sector in each country is taken to be the service and agricultural sectors. For Table 1-2, trade data is taken from the UNCOMTRADE database, and F.o.b. export values as reported by exporting countries are used. In Table 1-3 , oil use and trade data for 2006 are calculated from IEA oil statistics. The unit of account used in the IEA statistics data is thousands of tonnes of oil equivalent, which we adjust to billion US dollars, ( 1 toe=7.33 barrel of oil equivalent, oil price (average) $=\$ 61.08 /$ per barrel) . The extraction cost is calculated using the IEA energy balance table. In the data presented in Table 1-4, adjustments are made to consumption so as to be compatible with GDP minus exports. There are also some small differences in goods classifications between the underlying consumption, production and tariff rate data. Table 1-5 gives energy consumption data from IEA statistics. 
Table 1 Data Sources Used in Model Calibration

Table 1-1 2006 GDP by Sector by Region (Billion \$)

\begin{tabular}{ccccccccccc}
\hline & \multicolumn{2}{c}{ China } & \multicolumn{2}{c}{ EU-27 } & \multicolumn{2}{c}{ US } & \multicolumn{2}{c}{ OPEC } & \multicolumn{3}{c}{ ROW } \\
& High & Low & High & Low & High & Low & High & Low & High & Low \\
\hline $\begin{array}{l}\text { GDP by } \\
\text { sector }\end{array}$ & 1279.23 & 1378.64 & 3852.48 & 10694.22 & 3006.63 & 10157.27 & 1169.39 & 1084.26 & 4249.39 & 11755.19 \\
\multicolumn{1}{c}{ GDP } & 2657.87 & & 14546.7 & & 13163.9 & & 2253.65 & & 16004.58 \\
\hline
\end{tabular}

Source: World Bank’s WDI database, OPEC Annual Statistics Bulletin2007.

Table 1-2 2006 Bilateral Trade Data (Billion \$)

\begin{tabular}{|c|c|c|c|c|c|c|c|}
\hline \multicolumn{2}{|c|}{$\begin{array}{l}\text { Export by } \\
\text { (Billion \$) }\end{array}$} & $\begin{array}{c}\text { Import by } \\
\text { China }\end{array}$ & \multirow{2}{*}{$\begin{array}{c}\text { EU-27 } \\
159.05\end{array}$} & \multirow{2}{*}{$\begin{array}{r}\text { US } \\
139.22\end{array}$} & \multirow{2}{*}{$\begin{array}{r}\text { OPEC } \\
32.20\end{array}$} & \multirow{2}{*}{$\begin{array}{c}\text { ROW } \\
364.00\end{array}$} & \multirow{2}{*}{$\begin{array}{c}\text { World } \\
694.47\end{array}$} \\
\hline & High & 0.00 & & & & & \\
\hline \multirow[t]{3}{*}{ China } & Low & 0.00 & 85.42 & 64.58 & 8.80 & 115.66 & 274.46 \\
\hline & Total & 0.00 & 244.47 & 203.80 & 41.00 & 479.66 & 968.93 \\
\hline & High & 64.00 & 0.00 & 268.93 & 96.77 & 693.34 & 1123.04 \\
\hline \multirow[t]{3}{*}{ EU-27 } & Low & 15.29 & 0.00 & 65.82 & 24.60 & 230.71 & 336.42 \\
\hline & Total & 79.29 & 0.00 & 334.75 & 121.37 & 924.05 & 1459.46 \\
\hline & High & 35.33 & 159.52 & 0.00 & 36.08 & 535.94 & 766.87 \\
\hline \multirow[t]{3}{*}{ US } & Low & 19.89 & 59.63 & 0.00 & 8.80 & 181.84 & 270.16 \\
\hline & Total & 55.22 & 219.15 & 0.00 & 44.88 & 717.78 & 1037.03 \\
\hline & High & 20.20 & 147.08 & 113.10 & 0.00 & 388.91 & 669.29 \\
\hline \multirow{3}{*}{ OPEC } & Low & 3.47 & 15.09 & 9.27 & 0.00 & 72.09 & 99.92 \\
\hline & Total & 23.67 & 162.17 & 122.37 & 0.00 & 461.00 & 769.21 \\
\hline & High & 499.54 & 774.89 & 928.83 & 74.77 & 0.00 & 2278.03 \\
\hline \multirow[t]{3}{*}{ ROW } & Low & 133.74 & 297.04 & 329.24 & 90.86 & 0.00 & 850.88 \\
\hline & Total & 633.28 & 1071.93 & 1258.07 & 165.63 & 0.00 & 3128.91 \\
\hline & High & 619.07 & 1240.54 & 1450.08 & 239.82 & 1982.19 & 5531.70 \\
\hline \multirow[t]{2}{*}{ World } & Low & 172.39 & 457.18 & 468.91 & 133.06 & 600.30 & 1831.84 \\
\hline & Total & 791.46 & 1697.72 & 1918.99 & 372.88 & 2582.49 & 7363.54 \\
\hline
\end{tabular}

Source: UNCOMTRADE database

Table 1-3 2006 Oil Balance Data (Billion \$)

\begin{tabular}{|c|c|c|c|c|c|c|c|c|}
\hline & $\begin{array}{l}\text { Extrac- } \\
\text { tion }\end{array}$ & Import & Export & $\begin{array}{l}\text { Net } \\
\text { Import }\end{array}$ & $\begin{array}{l}\text { Extraction } \\
\text { cost }\end{array}$ & Consumption & $\begin{array}{l}\text { High } \\
\text { emission } \\
\text { sector input }\end{array}$ & $\begin{array}{l}\text { Low } \\
\text { Emission } \\
\text { sector input }\end{array}$ \\
\hline China & 82.76 & 85.17 & -9.70 & 75.47 & 22.09 & 136.14 & 76.27 & 59.87 \\
\hline Eu27 & 54.16 & 431.42 & -160.86 & 270.56 & 35.28 & 289.44 & 205.12 & 84.33 \\
\hline US & 142.29 & 321.18 & -29.20 & 291.97 & 35.82 & 398.44 & 307.09 & 91.35 \\
\hline OPEC & 782.97 & 35.92 & -635.90 & -599.98 & 39.71 & 143.27 & 103.03 & 40.23 \\
\hline ROW & 741.96 & 589.48 & -627.50 & -38.02 & 112.57 & 591.37 & 398.40 & 192.97 \\
\hline World & 1804.14 & 1463.17 & -1463.17 & 0.00 & 245.47 & 1558.67 & 1089.92 & 468.75 \\
\hline
\end{tabular}

Source: IEA oil statistics 
Table 1-4 Consumption of Domestic Goods (2006) (Billion \$)

\begin{tabular}{|c|c|c|}
\hline & \multicolumn{2}{|c|}{ Consumption of Domestic Goods } \\
\hline & $\begin{array}{c}\text { High oil } \\
\text { intensity goods }\end{array}$ & $\begin{array}{l}\text { Low oil } \\
\text { intensity goods }\end{array}$ \\
\hline China & 584.76 & 1104.18 \\
\hline Eu27 & 2729.44 & 10357.80 \\
\hline US & 2239.76 & 9887.11 \\
\hline OPEC & 500.10 & 984.34 \\
\hline ROW & 1971.36 & 10904.31 \\
\hline
\end{tabular}

Table 1-5 Energy Consumption (Billion US \$)

\begin{tabular}{crrrrr}
\hline Year & China & EU-27 & US & ROW & World \\
\hline 2006 & 412.96 & 483.69 & 593.20 & 1446.90 & 2936.75 \\
2036 & 80910.18 & 21510.37 & 30878.64 & 88533.37 & 221832.56 \\
2056 & 612633.64 & 47336.00 & 76757.82 & 250518.18 & 987245.64 \\
\hline \multicolumn{5}{l}{ Source: International Energy Agency: Key World Energy Statistics, 2008. }
\end{tabular}

As for elasticities, in the central case, model analyses elasticity parameters are used as follows: the consumption elasticity, that is the substitution elasticity between high and low emission goods in consumption is equal to 0.5 , and the trade elasticity , The substitution elasticities between domestic and imported commodities follows the "rule of two", that is the substitution elasticity between domestic and imported goods is equal to 2, as discussed in Hertel al. (2009). This rule was first proposed by Jomini et al.(1991) and later tested by Liu, Arndt,and Hertel(2002) in a back-casting exercise with a simplified version of the GTAP model.

For the production substitution elasticity, we assume values are the same in all countries and we use Lerner pricing by OPEC to calibrate them to the base data on the P-MC difference for oil extraction. We relate this difference to the implied oil demand elasticity, in non-OPEC countries as a point estimate at the benchmark equilibrium. Lerner's pricing rule implies:

$$
\frac{p_{E}-M C_{E}}{p_{E}}=\frac{1}{\varepsilon_{E}}
$$

where $p_{E}$ is the price of oil, $M C_{E}$ is the marginal cost of oil, and $\varepsilon_{E}$ is the price elasticity of oil demand. Thus if the oil price is ,say $\$ 60 /$ per barrel, and the 
marginal extraction cost is $\$ 12$, by equation (19), we get $\varepsilon_{E}=1.25$. We obtain the production side substitution elasticity $\sigma_{s}$ by iterative calculation of the arc estimate of the demand elasticity for oil facing OPEC in the model at the benchmark equilibrium. As shown in table 2 , when $\sigma_{s}=5.2$, the arc estimate of demand of oil produced in OPEC equals 1.25.

Using data for 2006,2036, and 2056 in table 1-5, and assuming the temperature change at these three points to be $0^{\circ} \mathrm{C}, 2^{\circ} \mathrm{C}$, and $5^{\circ} \mathrm{C}$ respectively, we can solve for the values of parameters a,b,and c in equation (15) as

$$
\begin{aligned}
& 0=a(2936.75-2936.75)^{\mathrm{b}}+c \\
& 2=a(221832.56)^{\mathrm{b}}+c \\
& 5=a(987245.64)^{\mathrm{b}}+c
\end{aligned}
$$

Solving these equations for the parameters a,b,and c yields values of 0.0010 ,

0.6137 and 0 . Substituting these values in the temperature equation yields

$$
\Delta T=g\left(\sum_{i} \sum_{j} E_{i j}\right)=0.001\left(\sum_{i} \sum_{j} E_{i j}\right)^{0.6137}
$$

Assuming a temperature change $\Delta T$ of $5^{\circ} \mathrm{C}$ between 2006 and 2056 (consistent with Stern(2002)), Table 2 reports the calibrated preference parameters in equation (10) under alternative damage assumptions. As discussed in Cai et al.(2009), the share parameter $\beta$ reflects the assumed severity of damage from temperature change. We assume $3 \%$ utility loss and $\beta=0.1059$.

Table 2 also reports remaining parameter values in production, preferences and extraction cost functions generated by calibration. These are independent of the assumed utility damage due to temperature change. 
Table 2 Calibrated Parameters

\section{A. Production Elasticity}

World oil demand

$\begin{array}{cc}\begin{array}{c}\text { production } \\ \text { elasticity }\end{array} & \text { Base value } \\ 5.00 & 1558.6700 \\ 5.20 & 1558.6700 \\ 5.30 & 1558.6700 \\ 5.50 & 1558.6700\end{array}$

Arc estimate at benchmark equilibrium of elasticity of oil demand

4.7290

4.9127

5.0045

5.1878
OPEC oil

production/World oil production

$25.43 \%$

$25.43 \%$

$25.43 \%$

$25.43 \%$
Elasticity of world demand on OPEC oil

1.2028

1.2495

1.2729 1.3195

\section{B. Assumed Changes in Preference Parameters}

Assumed utility loss in

BAU

Utility relative to no damage

$1 \% \quad 3 \%$

0.97

$5 \%$

$10 \%$

$15 \%$

$20 \%$

$\beta$

0.0349

0.1059

0.95

0.9

0.85

0.8

\section{Parameters in CES production functions}

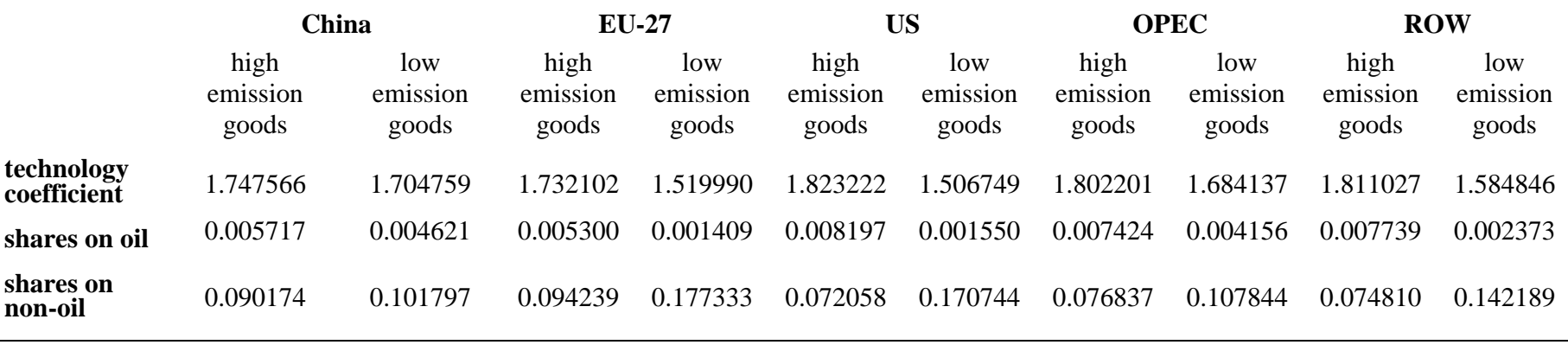

\section{Parameters in Nested CES Utility functions}

Shares of high and low energy (emission) composite goods

\begin{tabular}{cccccccccc}
\multicolumn{2}{c}{ China } & \multicolumn{2}{c}{ EU-27 } & \multicolumn{2}{c}{ US } & \multicolumn{2}{c}{ OPEC } & \multicolumn{2}{c}{ ROW } \\
$\begin{array}{c}\text { high emission } \\
\text { goods }\end{array}$ & $\begin{array}{c}\text { low } \\
\text { emission } \\
\text { goods }\end{array}$ & $\begin{array}{c}\text { high } \\
\text { emission } \\
\text { goods }\end{array}$ & $\begin{array}{c}\text { low } \\
\text { emission } \\
\text { goods }\end{array}$ & $\begin{array}{c}\text { high } \\
\text { emission } \\
\text { goods }\end{array}$ & $\begin{array}{c}\text { low } \\
\text { emission } \\
\text { goods }\end{array}$ & $\begin{array}{c}\text { high } \\
\text { emission } \\
\text { goods }\end{array}$ & $\begin{array}{c}\text { low } \\
\text { emission } \\
\text { goods }\end{array}$ & $\begin{array}{c}\text { high } \\
\text { emission } \\
\text { goods }\end{array}$ & $\begin{array}{c}\text { low } \\
\text { emission } \\
\text { goods }\end{array}$ \\
0.628868 & 0.777512 & 0.262631 & 0.964896 & 0.244520 & 0.969644 & 0.475327 & 0.879809 & 0.232531 & 0.972589
\end{tabular}

Shares of consumption of high energy (emission) domestic and import goods

$\begin{array}{lccccc} & \text { China } & \text { EU-27 } & \text { US } & \text { OPEC } & \text { ROW } \\ \text { China-H } & 0.124109 & 0.011915 & 0.010496 & 0.012533 & 0.021514 \\ \text { EU-H } & 0.016138 & 0.189772 & 0.020276 & 0.037665 & 0.04098 \\ \text { US-H } & 0.008909 & 0.01195 & 0.158553 & 0.014043 & 0.031677 \\ \text { OPEC-H } & 0.005094 & 0.011018 & 0.008527 & 0.163924 & 0.022986 \\ \text { ROW-H } & 0.125965 & 0.058049 & 0.070028 & 0.029102 & 0.103232\end{array}$

Shares of consumption of low energy (emission) domestic and import goods

\begin{tabular}{llcccc} 
China-L & 0.322971 & 0.005331 & 0.00373 & 0.003729 & 0.005801 \\
EU-L & 0.005997 & 0.488794 & 0.003801 & 0.010425 & 0.011571 \\
US-L & 0.007801 & 0.003722 & 0.51301 & 0.003729 & 0.00912 \\
OPEC-L & 0.001361 & 0.000942 & 0.000535 & 0.33585 & 0.003616 \\
ROW-L & 0.052457 & 0.018538 & 0.019014 & 0.038506 & 0.436446 \\
\hline
\end{tabular}

E. Parameters in Extraction functions

\begin{tabular}{lccccc} 
& China & EU-27 & US & OPEC & ROW \\
Constant Parameter & -33.0833 & -0.8267 & -59.0400 & -482.2700 & -382.0700 \\
Coefficient parameter & 0.0733 & 0.0906 & 0.0559 & 0.0238 & 0.0245 \\
\hline
\end{tabular}




\section{Model Experiments and Results for Carbon Tax and OPEC Monopoly Rent Transferring}

We have used our calibrated model to simulate the impacts of using a joint carbon tax by non-OPEC countries on global emissions and country welfare. The results of these experiments show that a uniform carbon tax used by non-OPEC countries will increase the buyer's price of oil and decreasing the producer price of oil, and thus decrease non-OPEC countries' oil demand, and transfer OPEC's monopoly rent to non-OPEC countries. A jointly implemented carbon tax with supporting trigger price strategies can thus reduce the welfare of OPEC and increase the effect of the welfare of non-OPEC countries. Non-OPEC countries' income increases from two sources: one is OPEC rent transferring, the other is carbon tax revenue. Carbon tax can decrease global emissions, but the effect is small.

In Tables $3-7$, we assume a uniform carbon tax rate adopted by non-OPEC countries (China, EU, US, ROW). By increasing the tax rate, we can analyze the effect of the carbon tax on oil price, oil demand, income, welfare and emissions.

Table 3 shows the impact of uniform carbon tax on the buyer's oil price. By increasing the carbon tax rate, the seller's price of oil will decrease and buyer's price of oil will increase. When the carbon tax rate is at $1 \%, 3 \%, 5 \%, 10 \%, 15 \%$ and $20 \%$, the seller's price of oil will change $-0.8745 \%,-2.5727 \%,-4.2061 \%,-8.0232 \%$, $-11.4900 \%$ and $-14.6397 \%$ accordingly, and the buyers price in all countries will change by $0.1168 \%, 0.3501 \%, 0.5836 \%, 1.1745 \%, 1.7864 \%$ and $2.4323 \%$ accordingly.

Table 3 Impacts of Uniform Carbon Tax on Buyer's Oil Price (\% Change Based on 2006 Data)

\begin{tabular}{ccccccc}
\hline CARBON TAX & \multicolumn{2}{c}{ \% Change in Oil Price } \\
& China & EU & US & OPEC & ROW & Total \\
\hline 1\% uniform carbon tax & $0.1168 \%$ & $0.1168 \%$ & $0.1168 \%$ & $-0.8745 \%$ & $0.1168 \%$ & $0.1168 \%$ \\
3\% uniform carbon tax & $0.3501 \%$ & $0.3501 \%$ & $0.3501 \%$ & $-2.5727 \%$ & $0.3501 \%$ & $0.3501 \%$ \\
5\% uniform carbon tax & $0.5836 \%$ & $0.5836 \%$ & $0.5836 \%$ & $-4.2061 \%$ & $0.5836 \%$ & $0.5836 \%$ \\
$10 \%$ uniform carbon tax & $1.1745 \%$ & $1.1745 \%$ & $1.1745 \%$ & $-8.0232 \%$ & $1.1745 \%$ & $1.1745 \%$ \\
$15 \%$ uniform carbon tax & $1.7864 \%$ & $1.7864 \%$ & $1.7864 \%$ & $-11.4900 \%$ & $1.7864 \%$ & $1.7864 \%$ \\
20\% uniform carbon tax & $2.4323 \%$ & $2.4323 \%$ & $2.4323 \%$ & $-14.6397 \%$ & $2.4323 \%$ & $2.4323 \%$ \\
\hline
\end{tabular}


Table 4 reports the consumption of oil in non-OPEC importing countries reducing with the increasing of carbon tax rate. When the carbon tax rate is $1 \%$, the oil demand of China, EU, US and ROW decreases by $0.5683 \%, 0.5800 \%, 0.5555 \%, 0.5755 \%$. When the carbon tax rate increases to $10 \%$, the oil demand of China, EU, US and ROW decreases by 5.4613\%, 5.6185\%, 5.3800\%, 5.5395\%.

Table 4 Impacts of Uniform Carbon tax on Oil Demand (\% Change Based on 2006 Data)

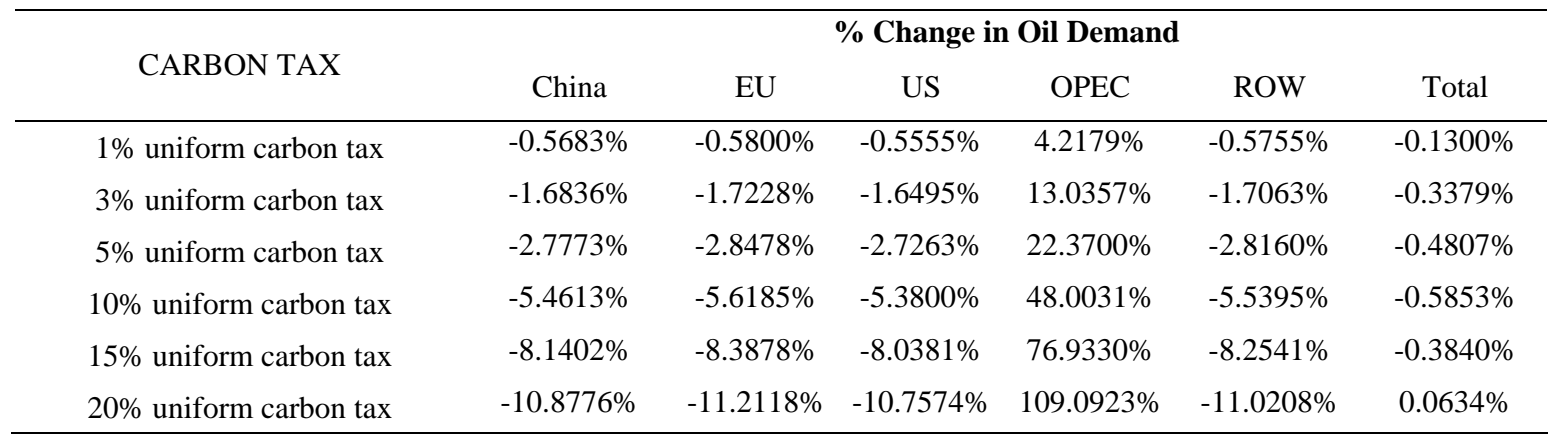

The results in Table 3 and Table 4 thus confirm the idea that taxation in an importing country implies a transfer of rents from producers to consumers. Since OPEC has high monopoly power in oil production, a jointly implemented carbon tax functions as an effective way to reduce OPEC's monopoly power.

Table 5 reports the influence of carbon taxes on OPEC and non-OPEC country's incomes. Non-OPEC countries increase their income due to rent transfers from OPEC and carbon tax revenue. When the carbon tax rate is 3\%, the income of China, EU, US and ROW increases by $0.0937 \%, 0.0540 \%, 0.0663 \%, 0.0034 \%$, OPEC's income falls by $1.0598 \%$. When the carbon tax rate increases to $20 \%$, the income of China, EU, US and ROW increases by $0.8187 \%, 0.3943 \%, 0.5137 \%, 0.2590 \%$. OPEC's income falls by $5.3335 \%$. For non-OPEC countries, the income increases are small. 
Table 5 Impacts of Uniform Carbon Tax on Income

(\% Change Based on 2006 Data)

\begin{tabular}{ccccccc}
\hline CARBON TAX & \multicolumn{5}{c}{ \% Change in Income } \\
& China & EU & US & OPEC & ROW & Total \\
\hline 1\% uniform carbon tax & $0.0279 \%$ & $0.0171 \%$ & $0.0206 \%$ & $-0.3664 \%$ & $-0.0019 \%$ & $-0.0022 \%$ \\
3\% uniform carbon tax & $0.0937 \%$ & $0.0540 \%$ & $0.0663 \%$ & $-1.0598 \%$ & $0.0034 \%$ & $0.0005 \%$ \\
5\% uniform carbon tax & $0.1683 \%$ & $0.0932 \%$ & $0.1158 \%$ & $-1.7044 \%$ & $0.0178 \%$ & $0.0103 \%$ \\
10\% uniform carbon tax & $0.3778 \%$ & $0.1954 \%$ & $0.2483 \%$ & $-3.1282 \%$ & $0.0806 \%$ & $0.0554 \%$ \\
$15 \%$ uniform carbon tax & $0.6002 \%$ & $0.2974 \%$ & $0.3835 \%$ & $-4.3241 \%$ & $0.1656 \%$ & $0.1178 \%$ \\
20\% uniform carbon tax & $0.8187 \%$ & $0.3943 \%$ & $0.5137 \%$ & $-5.3335 \%$ & $0.2590 \%$ & $0.1868 \%$ \\
\hline
\end{tabular}

In Table 6, we use Hicksian CV and EV measures capturing the effects of temperature change for welfare analysis. These are

$$
\begin{gathered}
C V_{i}=\frac{\Delta U_{i}}{\left(\frac{C_{i}-\Delta T_{0}}{C_{i}}\right)^{\beta}}=\frac{U_{i}^{1}-U_{i}^{0}}{\left(\frac{C_{i}-\Delta T_{0}}{C_{i}}\right)^{\beta}} \\
E V_{i}=\frac{\Delta U_{i}}{\left(\frac{C_{i}-\Delta T_{1}}{C_{i}}\right)^{\beta}}=\frac{U_{i}^{1}-U_{i}^{0}}{\left(\frac{C_{i}-\Delta T_{1}}{C_{i}}\right)^{\beta}}
\end{gathered}
$$

Since the temperature change is small, $\Delta T_{0} \approx \Delta T_{1}$, and CV and EV measures from equations (21) and (22) are similar. We only report the CV measure. Results show that non-OPEC countries improve welfare and OPEC loses welfare. When the carbon tax rate is $5 \%$, CV measures for China, EU, US and ROW are 0.000043, 3.710793, 4.440146, 0.487235, CV of OPEC is -5.122175 , When the carbon tax rate is $20 \%$, CV measures for China, EU, US and ROW are 0.000216, 15.897682, 20.049688 , 10.130895. The CV of OPEC is -15.12791 .

Table 6 Impacts of Uniform Carbon tax on welfare (CV)

\begin{tabular}{ccccccc}
\hline \multirow{2}{*}{ CARBON TAX } & \multicolumn{6}{c}{ Change in Welfare by Region (CV) } \\
& China & EU & US & OPEC & ROW & Total \\
\hline 1\% uniform carbon tax & 0.000007 & 0.672325 & 0.774374 & -1.115139 & -0.138067 & 0.286138 \\
3\% uniform carbon tax & 0.000023 & 2.140034 & 2.520218 & -3.205549 & -0.022011 & 4.100982 \\
5\% uniform carbon tax & 0.000043 & 3.710793 & 4.440146 & -5.122175 & 0.487235 & 12.503942 \\
10\% uniform carbon tax & 0.000098 & 7.841789 & 9.630654 & -9.238164 & 2.924413 & 12.503942 \\
15\% uniform carbon tax & 0.000158 & 11.981790 & 14.953226 & -12.526053 & 6.339063 & 22.907469 \\
20\% uniform carbon tax & 0.000216 & 15.897682 & 20.049688 & -15.127910 & 10.130895 & 33.906084 \\
\hline
\end{tabular}


Table 7 reports the effects of carbon tax on emissions. The global emissions decrease with an increasing carbon tax rate, but the effect is small. When the uniform carbon tax rate is 20\%, global emissions decrease by $3.3599 \%$. Across different regions, OPEC increases emissions since OPEC does not use a carbon tax, while non-OPEC countries decrease emissions due to reduced oil consumption.

\section{Table7 Impacts of Uniform Carbon Tax on Emissions(Oil Use) (\% Change Based on 2006 Data)}

\begin{tabular}{ccccccc}
\hline CARBON TAX & \multicolumn{2}{c}{ \% Change } & in Emissions \\
& China & EU & US & OPEC & ROW & Total \\
\hline 1\% uniform carbon tax & $-0.5683 \%$ & $-0.5800 \%$ & $-0.5555 \%$ & $4.2179 \%$ & $-0.5756 \%$ & $-0.2671 \%$ \\
3\% uniform carbon tax & $-1.6836 \%$ & $-1.7229 \%$ & $-1.6495 \%$ & $13.0357 \%$ & $-1.7063 \%$ & $-0.7590 \%$ \\
5\% uniform carbon tax & $-2.7773 \%$ & $-2.8478 \%$ & $-2.7263 \%$ & $22.3700 \%$ & $-2.8160 \%$ & $-1.1997 \%$ \\
10\% uniform carbon tax & $-5.4612 \%$ & $-5.6185 \%$ & $-5.3800 \%$ & $48.0031 \%$ & $-5.5395 \%$ & $-2.1121 \%$ \\
15\% uniform carbon tax & $-8.1402 \%$ & $-8.3878 \%$ & $-8.0381 \%$ & $76.9330 \%$ & $-8.2541 \%$ & $-2.8121 \%$ \\
20\% uniform carbon tax & $-10.8776 \%$ & $-11.2118 \%$ & $-10.7574 \%$ & $109.0923 \%$ & $-11.0208 \%$ & $-3.3599 \%$ \\
\hline
\end{tabular}




\section{Concluding Remarks}

We have used a multi-region general equilibrium model calibrated to 2006 benchmark data to evaluate the impacts of jointly imposed carbon taxes on OPEC and non-OPEC countries' oil consumption, income, emissions and welfare. Our results confirm the view that carbon taxes can have a third benefit for oil importing countries of transferring rents from OPEC to oil importing countries and reducing OPEC's monopoly power on oil market.

Results from model analysis also show that a uniform carbon tax by non-OPEC countries will increase the buyer's price of oil and decrease the seller's price of oil, thus decreasing non-OPEC countries' oil demand, and transferring OPEC's monopoly rent to non-OPEC countries. A carbon tax thus reduces the welfare of OPEC and increases the welfare of non-OPEC countries. Non-OPEC countries' income can increase from two sources: one is OPEC rent transfers; the other is from carbon tax revenue. A non-OPEC carbon tax can decrease global emissions, but the effect is small. 


\section{References}

Barnett,J., S.Dessai \& M.Webber(2004) “Will OPEC Lose from the Kyoto Protocol?”, Oil Policy,32, PP.2077-2088.

Bernstein,P.,D.Montgomery,T.Rutherford \& G.Yang (1999). "Effects of Restrictions on International Permit Trading: the MS-MRT Model”, The Oil Journal, pp.221-256.

Bhattacharyya, S.C.(1996) “Applied General Equilibrium Models for Oil Studies: A Survey”, Oil Economics ,Vol.18 ,pp.145-164.

Cai,Y,Z, R.Riezman and J. Whalley(2009) “International Trade and the Negotiability of Global Climate Change Agreements”, NBER Working Paper No.14711, Issued in Feb 2009.

Cooke,R.(2007) “The elasticity of oil production and consumption”, Oil Bulletin, Archived Mar 222007.

Dong,Y. \& J. Whalley (2008) “Carbon, Trade Policy, and Carbon Free Trade Areas”, NBER Working Paper No.14431, Issued in October 2008.

Dong,Y. \& J. Whalley (2009) “Carbon Motivated Regional Trade Arrangements: Analytics and Simulations”, NBER Working Paper No.14880, Issued in April 2009.

Ghanem,S.,R.Lounnas \& G.Rennand(1999) “The Impact of Emissions Trading on OPEC”, OPEC Review, 23,pp.79-112.

Hertel, T., R. McDougall, B.Narayanan and A.H. Aguiar(2009) “GTAP 7 Data Base Documentation - Chapter 14: Behavioral Parameters", access at https://www.gtap.agecon.purdue.edu/resources/download/4184.pdf

Jomini, P., J.F. Zeitsch, R. McDougall, A. Welsh, S. Brown, J.Hambley and J. Kelly(1991) "SALTER: A General Equilibrium Model of the World Economy”, Vol. 1. Model Structure, Data Base, and Parameters. Canberra, Australia: Industry Commission.

Kemfert,C.(1998)“Estimated Substitution Elasticities of a Nested CES Production Function Approach for Germany. Oil Economics 20 3, pp. 249-264.

Lerner, A.P.(1934) "The Concept of Monopoly and the Measurement of Monopoly Power” The Review of Economic Studies, Vol.1,No.3 pp.157-175.

Lerner, A.P.(1980) “OPEC—A Plan-If You Can't Beat Them, Join Them”, Atlantic Economic Journal ,pp.1-3.

Liu, J., Y. Surry, B. Dimaranan and T. Hertel(1998) “CDE Calibration,” Chapter 21 in Robert McDougall, Aziz Elbehri, and Truong P. Truong. Global Trade, 
Assistance and Protection: The GTAP 4 Data Base, Center for Global Trade Analysis, Purdue University, West Lafayette, Indiana.

Manne, A. S. and R. G. Richels(1999) "The Kyoto Protocol: A Cost-Effective Strategy for Meeting Environmental Objectives?” in The Costs of the Kyoto Protocol: A Multi-Model Evaluation, John Weyant (ed.), Special Issue of The Oil Journal.

McKibbin,W., T.Ross, R. Shackleton \& P.Wilcoxen (1999) “Emissions Trading, Capital Flows and the Kyoto Protocol”,The Oil Journal,pp.287-335.

Mendelsohn, Robert, O.(2006) A Critique of the Stern Report, Regulation.(Winter 2006-2007), pp.42-46.

OPEC(2008), OPEC Annual Statistical Bulletin 2007, OPEC Website.

Pearce, D.(1991) “The Role of Carbon Taxes in Adjusting to Global Warming”, The Economic Journal 101, pp.938-948.

Pigou,A.C.(1938) The Economics of Welfare, $4^{\text {th }}$ ed. London: MacMillan and Company.

Stern,N. (2006) Stern Review on the Economics of Climate Change. (Cambridge Univ Press, Cambridge, UK).

Terkla, D.(1984) ,“The Efficiency Value of Effluent Tax Revenues”, Journal of Environmental Economics and Management, 11, pp. 107-123. 


\section{CESifo Working Paper Series}

for full list see www.cesifo-group.org/wp

(address: Poschingerstr. 5, 81679 Munich, Germany, office@cesifo.de)

2677 Rolf Golombek and Michael Hoel, International Cooperation on Climate-Friendly Technologies, June 2009

2678 Martin Cave and Matthew Corkery, Regulation and Barriers to Trade in Telecommunications Services in the European Union, June 2009

2679 Costas Arkolakis, A Unified Theory of Firm Selection and Growth, June 2009

2680 Michelle R. Garfinkel, Stergios Skaperdas and Constantinos Syropoulos, International Trade and Transnational Insecurity: How Comparative Advantage and Power are Jointly Determined, June 2009

2681 Marcelo Resende, Capital Structure and Regulation in U.S. Local Telephony: An Exploratory Econometric Study; June 2009

2682 Marc Gronwald and Janina Ketterer, Evaluating Emission Trading as a Policy Tool Evidence from Conditional Jump Models, June 2009

2683 Stephan O. Hornig, Horst Rottmann and Rüdiger Wapler, Information Asymmetry, Education Signals and the Case of Ethnic and Native Germans, June 2009

2684 Benoit Dostie and Rajshri Jayaraman, The Effect of Adversity on Process Innovations and Managerial Incentives, June 2009

2685 Peter Egger, Christian Keuschnigg and Hannes Winner, Incorporation and Taxation: Theory and Firm-level Evidence, June 2009

2686 Chrysovalantou Milliou and Emmanuel Petrakis, Timing of Technology Adoption and Product Market Competition, June 2009

2687 Hans Degryse, Frank de Jong and Jérémie Lefebvre, An Empirical Analysis of Legal Insider Trading in the Netherlands, June 2009

2688 Subhasish M. Chowdhury, Dan Kovenock and Roman M. Sheremeta, An Experimental Investigation of Colonel Blotto Games, June 2009

2689 Alexander Chudik, M. Hashem Pesaran and Elisa Tosetti, Weak and Strong Cross Section Dependence and Estimation of Large Panels, June 2009

2690 Mohamed El Hedi Arouri and Christophe Rault, On the Influence of Oil Prices on Stock Markets: Evidence from Panel Analysis in GCC Countries, June 2009

2691 Lars P. Feld and Christoph A. Schaltegger, Political Stability and Fiscal Policy - Time Series Evidence for the Swiss Federal Level since 1849, June 2009 
2692 Michael Funke and Marc Gronwald, A Convex Hull Approach to Counterfactual Analysis of Trade Openness and Growth, June 2009

2693 Patricia Funk and Christina Gathmann, Does Direct Democracy Reduce the Size of Government? New Evidence from Historical Data, 1890-2000, June 2009

2694 Kirsten Wandschneider and Nikolaus Wolf, Shooting on a Moving Target: Explaining European Bank Rates during the Interwar Period, June 2009

2695 J. Atsu Amegashie, Third-Party Intervention in Conflicts and the Indirect Samaritan's Dilemma, June 2009

2696 Enrico Spolaore and Romain Wacziarg, War and Relatedness, June 2009

2697 Steven Brakman, Charles van Marrewijk and Arjen van Witteloostuijn, Market Liberalization in the European Natural Gas Market - the Importance of Capacity Constraints and Efficiency Differences, July 2009

2698 Huifang Tian, John Whalley and Yuezhou Cai, Trade Sanctions, Financial Transfers and BRIC's Participation in Global Climate Change Negotiations, July 2009

2699 Axel Dreher and Justina A. V. Fischer, Government Decentralization as a Disincentive for Transnational Terror? An Empirical Analysis, July 2009

2700 Balázs Égert, Tomasz Koźluk and Douglas Sutherland, Infrastructure and Growth: Empirical Evidence, July 2009

2701 Felix Bierbrauer, Optimal Income Taxation and Public Goods Provision in a Large Economy with Aggregate Uncertainty, July 2009

2702 Marc Gronwald, Investigating the U.S. Oil-Macroeconomy Nexus using Rolling Impulse Responses, July 2009

2703 Ali Bayar and Bram Smeets, Government Deficits in the European Union: An Analysis of Entry and Exit Dynamics, July 2009

2704 Stergios Skaperdas, The Costs of Organized Violence: A Review of the Evidence, July 2009

2705 António Afonso and Christophe Rault, Spend-and-tax: A Panel Data Investigation for the EU, July 2009

2706 Bruno S. Frey, Punishment - and beyond, July 2009

2707 Michael Melvin and Mark P. Taylor, The Crisis in the Foreign Exchange Market, July 2009

2708 Firouz Gahvari, Friedman Rule in a Model with Endogenous Growth and Cash-inadvance Constraint, July 2009 
2709 Jon H. Fiva and Gisle James Natvik, Do Re-election Probabilities Influence Public Investment?, July 2009

2710 Jarko Fidrmuc and Iikka Korhonen, The Impact of the Global Financial Crisis on Business Cycles in Asian Emerging Economies, July 2009

2711 J. Atsu Amegashie, Incomplete Property Rights and Overinvestment, July 2009

2712 Frank R. Lichtenberg, Response to Baker and Fugh-Berman's Critique of my Paper, "Why has Longevity Increased more in some States than in others?", July 2009

2713 Hans Jarle Kind, Tore Nilssen and Lars Sørgard, Business Models for Media Firms: Does Competition Matter for how they Raise Revenue?, July 2009

2714 Beatrix Brügger, Rafael Lalive and Josef Zweimüller, Does Culture Affect Unemployment? Evidence from the Röstigraben, July 2009

2715 Oliver Falck, Michael Fritsch and Stephan Heblich, Bohemians, Human Capital, and Regional Economic Growth, July 2009

2716 Wladimir Raymond, Pierre Mohnen, Franz Palm and Sybrand Schim van der Loeff, Innovative Sales, R\&D and Total Innovation Expenditures: Panel Evidence on their Dynamics, July 2009

2717 Ben J. Heijdra and Jochen O. Mierau, Annuity Market Imperfection, Retirement and Economic Growth, July 2009

2718 Kai Carstensen, Oliver Hülsewig and Timo Wollmershäuser, Price Dispersion in the Euro Area: The Case of a Symmetric Oil Price Shock, July 2009

2719 Katri Kosonen and Gaëtan Nicodème, The Role of Fiscal Instruments in Environmental Policy, July 2009

2720 Guglielmo Maria Caporale, Luca Onorante and Paolo Paesani, Inflation and Inflation Uncertainty in the Euro Area, July 2009

2721 Thushyanthan Baskaran and Lars P. Feld, Fiscal Decentralization and Economic Growth in OECD Countries: Is there a Relationship?, July 2009

2722 Nadia Fiorino and Roberto Ricciuti, Interest Groups and Government Spending in Italy, 1876-1913, July 2009

2723 Andreas Wagener, Tax Competition, Relative Performance and Policy Imitation, July 2009

2724 Hans Fehr and Fabian Kindermann, Pension Funding and Individual Accounts in Economies with Life-cyclers and Myopes, July 2009

2725 Ernesto Reuben and Arno Riedl, Enforcement of Contribution Norms in Public Good Games with Heterogeneous Populations, July 2009 
2726 Kurt Schmidheiny and Marius Brülhart, On the Equivalence of Location Choice Models: Conditional Logit, Nested Logit and Poisson, July 2009

2727 Bruno S. Frey, A Multiplicity of Approaches to Institutional Analysis. Applications to the Government and the Arts, July 2009

2728 Giovanni Villani, A Strategic R\&D Investment with Flexible Development Time in Real Option Game Analysis, July 2009

2729 Luca Di Corato and Michele Moretto, Investing in Biogas: Timing, Technological Choice and the Value of Flexibility from Inputs Mix, July 2009

2730 Gilad D. Aharonovitz, Nathan Skuza and Faysal Fahs, Can Integrity Replace Institutions? Theory and Evidence, July 2009

2731 Michele Moretto and Sergio Vergalli, Managing Migration through Conflicting Policies: an Option-theory Perspective, July 2009

2732 Volker Nitsch, Fly or Cry: Is Airport Noise Costly?, July 2009

2733 Francesco Cinnirella and Joachim Winter, Size Matters! Body Height and Labor Market Discrimination: A Cross-European Analysis, July 2009

2734 Samuel Bowles and Sandra Polanía Reyes, Economic Incentives and Social Preferences: A Preference-based Lucas Critique of Public Policy, July 2009

2735 Gary Burtless, Lessons of the Financial Crisis for the Design of National Pension Systems, July 2009

2736 Helmuth Cremer, Firouz Gahvari and Pierre Pestieau, Fertility, Human Capital Accumulation, and the Pension System, July 2009

2737 Hans Jarle Kind and Frank Stähler, Market Shares in Two-Sided Media Industries, July 2009

2738 Pamela Campa, Alessandra Casarico and Paola Profeta, Gender Culture and Gender Gap in Employment, August 2009

2739 Sebastian Gechert, Supplementary Private Health Insurance in Selected Countries: Lessons for EU Governments?, August 2009

2740 Leif Danziger, Endogenous Monopsony and the Perverse Effect of the Minimum Wage in Small Firms, August 2009

2741 Yan Dong and John Whalley, A Third Benefit of Joint Non-OPEC Carbon Taxes: Transferring OPEC Monopoly Rent, August 2009 